An International Journal of Language, Literature and Gender Studies (LALIGENS)

Ethiopia

Vol. 3 (2), Serial No 8, May, 2014:1-11

ISSN: 2225-8604(Print) ISSN 2227-5460 (Online)

http://dx.doi.org/10.4314/laligens.v3i2.1

\title{
ENHANCING THE NIGERIAN EDUCATIONAL SYSTEM THROUGH CREATIVE DRAMATICS
}

\author{
OLANIYAN, MODUPE ELIZABETH, Ph.D. \\ Department of English and Literary Studies \\ Ekiti State University, Ado-Ekiti \\ Tel. +2348038255313; +2348151515313 \\ E-mail:olaniyan_modupe@ymail.com
}

\begin{abstract}
In every organized society, there exists certain belief as to what its educational philosophy should satisfy. These beliefs are hinged on the objectives which the society intends to achieve through its process of education and training. The main focus of this paper is to make a strong case for the need for the educational authorities in Nigeria to recognize the fact that the country's professional theatre requires to be nurtured and sustained through a vibrant pedagogical drama. This is because, as with all human preoccupations, the love and appreciation of drama is a habit that requires to be cultivated, nurtured and sustained right from adolescence. The paper discusses creative dramatics as a symbolic tool for educational development. It also clarifies the meaning and objectives of creative dramatics as well as the functions of drama. It reviews the current deplorable
\end{abstract}


educational system in Nigeria and concludes that if our educational policy-makers are able to muster political will, a feasible blue-print for the ultimate realization of the long-awaited dream of educational drama in Nigerian school and colleges would soon emerge. The paper therefore recommends that drama education should be considered part of the total education of the average Nigerian since it stresses the cultural enrichment of the nation. Consequently, Nigeria's educational institutions should place greater emphasis on the creation of institutional strategies that will enhance life-long national development through educational drama or creative dramatics.

Key words: Adolescent, Creative Dramatics, Development, Education, Enhancement.

\section{Introduction}

The role of drama in education is a concern which has stimulated scholarly interest since the symbols of human communication have been known to have been recorded. According to Plato, cited in Harley (2006:20), drama being the imitation of appearance cannot be a good source of knowledge. Also, because of its emotional nature, it was suspected for its effects of corrupting the audience; hence, censorship of drama was proscribed in the ideal state. But in terms of the Aristotelean doctrine of catharsis in his 'Poetics', in which a good play purges the spectators of the emotions of pity and fear, drama was used as a guide for good conduct.

Drama, at its best, is one of the most salutary pastimes for a nation's citizenry, providing a rich avenue for continuous education and development. The art of stage performance is a powerful educational tool. Drama in education or creative dramatics involves a playing out of life situations which challenges the child's social attitude, his verbal control and language ability, his unselfishness, his physical energies and his imagination, as he lives through the situations of interest to him. 
The school is a microcosm of life, with passing glimpses of the real problems and pleasures of the larger society. Thus, education is increasingly viewed as a life-time process in which formal schooling plays only a part. Confidence and moral discernment are two of the many sterling virtues which correct and prolonged drama training is capable of inculcating in young people.

\section{Conceptual Framework}

Fafunwa (1974:54) declares that "education consists essentially in the imitation of others into a public world picked out by the language and concept of a people and structured by the rules governing their purposes and interactions with each other". Education, he asserts further, is a far more profound concept than 'training' because the latter is often used in a specialized sense, whereas, education is no longer compatible with any narrowly conceived enterprise.

Implying that education is a means of preparing the child for the challenges of life, R.S. Peter (1993:18) opines that the hallmark of a good school is the extent to which it kindles in its pupils a desire to go on with the things which they have been initiated when the pressures are off and when there is no extrinsic reason for engaging in them.

In the same vein, Mary Warnock (2003:12) stresses the significance of the development of the imaginative faculty in the educational process. According to her, "a good education must above all things be directed towards the strengthening of the faculty of imagination", which enables the child to go on with a subject beyond the point at which the teaching stops.

In a related development, Castle (1996:51) identifies the point of interface between education and the environment while postulating the development of personality and character as the principal objective of education. He offers what amounts to a drama-oriented definition of education thus:

The general purpose of education is to foster the growth of what is individual in each human being, at 
the same time harmonizing the individuality thus educed with the organic unity of the social group to which the individual belongs.

He goes on to highlight the relationship between education and drama, suggesting that drama encourages the development of individual personal resources. These resources are those of sensory perception, intellect, imagination, powers of concentration, physical and verbal skills and emotional control.

In its simplest form, creative dramatics can be defined as an organized and scientific application of drama in educational communication (Umukoro, 2002:11). The Oxford Advance Dictionary of Current English (2005) defines "dramatics" as "performance of plays", while the qualifying word "creative" highlights its principal goal, which is 'creativity', rather than the sheer interpretation of scripted drama. Creative dramatics is synonymous with educational drama, a kind of exploratory drama that takes the individual child involved on a voyage of self discovery through the free but creative process of self expression.

It is worth pointing out that the goal of creative dramatics or educational drama is not to produce future theatre practitioners, although the dramatic experience is quite capable of stimulating the love of theatre within some of the children. Creative dramatics is developmental drama from which every child is expected to benefit, regardless of his or her professional ambition.

Ten of the basic objectives of creative dramatics as identified by Umukoro (2002:31) are enumerated as:

- To encourage self-expression which leads to self discovery

- To promote self-awareness and diminish negative selfconsciousness.

- To develop the listening powers (as different from the natural hearing faculty) in the child. 
- To sharpen the child's perception and capability to observe minute details (as different from the natural use of the eyes)

- To develop the other human senses to the full maximum effectiveness.

- To sharpen the child's power of imagination and concentration resulting in specific forms of creativity based on individual talent;

- To promote and refine the powers of speech and effective communication.

- To facilitate social integration through group interaction and a sense of mutual understanding.

- To assist the child to develop into a full and rounded personality.

All these merits are in addition to the basic goal of effective impartation of knowledge and the vivification of other academic disciplines. Thus, when we talk of educational drama, we mean drama as part of the human life and a medium of natural development and communication.

\section{A Review of the Current Educational System in Nigeria}

Although, there are broad educational principles common to all, each society serves as the point of reference in the nature and quality of education offered its members. Education is a bilateral process; development of the internal skills inherent in the child, while at the same time inculcating in him external knowledge about his immediate world and the universe at large.

However, the educational system currently operating in Nigeria does not seem to prepare Nigerians adequately for solving their problems; taking pride in the things that are Nigerians, or identifying themselves with Nigerian culture and appreciating the unity in diversity philosophy of the country. Instead, the system tends to imitate the 
western world, which is dried up by a mechanical civilization that sacrifices everything including life for its own sake. The effect is that Nigerian education does not seem to have a name, character, relevance, identity or personality and thus cannot ensure Nigeria's continued role in education in Africa.

The problems inherent in Nigeria's educational system today appears to be the result of juxtaposing an educational system supposed to serve one culture with another, causing Nigerians to be misfits in their own culture. This practice negates the whole purpose of education and personifies education as an ornament which outwardly enhances the wearer without inwardly improving him and making him functional in the society.

Nigeria's Third National Development Plan stresses five main objectives which were re-echoed in the Fourth National Development Plan. These include: building of a free and democratic society (which we are presently enjoying) a just and egalitarian dynamic economy and a land of bright and full of opportunities for all citizens. These plans together with the National Education Policy have proposed that the quality of instruction at all levels of education be oriented towards inculcating the values of discipline, culture, team work and participation in those activities which foster character training and role-playing.

A report by UNESCO (1993) on the development of higher education in Africa observes that higher educational establishments mindful of the cultural needs of the community as a whole should further expand their activities and organize general introduction courses on African cultures. This conception that higher education should be involved in the cultural studies of its immediate environment is an eloquent testimony of the fact that the knowledge acquired there from should arm the individual to better solve the problems of that society. 


\section{Enhancing the Nigerian Educational System through Educational Drama}

Educational drama philosophy is an inclusive system of thought which embraces general education. It is a unique interdisciplinary approach which sees things together or views everything at once. It further sees teaching as a performing art and believes that the artist-teacher or teacher-artist has an exciting mode of communicating messages in a learning situation. Owning to its comprehensive nature and its unifying characteristic, its synoptic philosophy seems indispensable in Nigeria's educational and national development.

Educational drama proposes the utilization of the rich cultural elements of Nigerian life in instruction to better achieve the aims of education in Nigeria and for Nigerians. It seeks to inculcate cultural pride, national consciousness and the ability to make valid judgment as a way of ensuring relevance in Nigerian's educational system. The programme further recognizes that educational institutions exists to prepare young people for the future and therefore works towards a better future for Nigeria, a future less fraught with bias, suspicion, fear and hatred and therefore a more united future for the nation. The programme also aims at helping the teacher or the student to fit into the socio-cultural life of his environment and believes that the acquisition of such socio-cultural concepts can be enhanced through the reading and dramatizing of plays relevant to the teacher-student culture wherein he may discover the beauty of life, the lesson of history, the problems of society, his traditions and his rich cultural heritage.

Dramatic education is thus indispensable to true education. It is as Richard Courtney (1998:57) posits, "at the basis of all education that is child-centered". It is the way in which the life process develops and without it, man is merely one of the upper primates. "Paidocentric education", to borrow a term coined by John Adams (cited in Courtney, 1998:41) places the child at the very cornerstone of educational philosophy with the fundamental objective of developing 
his or her personality to the fullest possible extent. This objective can be most effectively realized through educational drama, which encourages the development of imagination and creativity. According to Mary Warnock (1993:112), a good education must above all things, be directed towards the strengthening of the faculty of imagination.

In his exploration of the individual, social and cultural functions of drama, Gordon Vallins (in John Russel Brown, ed. 2001:165), identifies four basic expressive resources for meaningful exploitation in creative communication, which he lists as

1. The use of the body in movement and dance in the manipulation of environment, including machines.

2. The articulation of sound through the use of voice in speech and song and through the use of instruments both primitive and sophisticated in the creation of rhythm and melody.

3. The use of Visual symbols in painting and the arrangement of objects into meaningful patterns as in sculpture collage.

4. The use of the written word.

In a nutshell, these expressive resources can be subsumed as the physical, the oral/aural, the visual and the literacy, thus offering a comprehensive diet of artistic creativity. Each expressive resource demands the use of concentration, intelligence, imagination and sensitivity, and dramatic activity sets up and controls the learning situation in which these personal resources are exercised. In essence, this is why educational drama's inter disciplinary approach to learning is being proposed as a very careful yet subtle way of changing the present curriculum existing in the nation's educational system and of ensuring cooperation and unity in Nigeria. 


\section{Conclusion}

The curricular status of drama has been the subject of serious controversy ever since it made its incursion into formal education. Drama has always been seen as a mode of communication and a method of teaching other subjects, but not as a subject worth serious academic attention in its own right in our pre-varsity educational system. This position obviously stems from a combination of prejudice and ignorance. What is there to teach or learn about drama anyway, other than acting and dancing? It is as untenable as treating drama as a mere appendage to literature or literary studies because in either situation, the autonomy of drama as a curricular discipline is compromised.

However, drama is not just another subject but one with adequate interdisciplinary capacity. While its dramatic method will continue to rank high in educational principles and philosophy, the recognition and promotion of drama as a distinct school subject (as different from forming dramatic societies) will further enhance its role as drama functions as a tool for teaching other subjects, but the value of a tool, any tool at all, depends on the amount of maintenance attention it receives. An autonomous drama department in our nursery, primary and secondary school systems will provide clearer guidelines on the use of drama as an effective teaching method without losing sight of its fundamental objectives. Hence, the success of drama as a method is inextricably bound up with its progress as a curricular subject in its own right.

\section{Recommendations}

Considering the enormous capabilities of using educational drama to enhance the nation's educational systems, the following recommendations are hereby suggested:

- Drama education should be recognized by state and federal government as a required component of every educational programme of the nation. The large number of universities 
establishing Theatre Arts Departments has pointed out the strong and increased interest in the role of drama education in national and educational development.

- Drama education should be considered part of total education of the average Nigerian since it stresses the cultural enrichment of Nigerians. Consequently educational institutions from nursery to university should place greater emphasis on the creation of instructional strategies which will enhance the lifelong national development.

- Drama education provides occupational opportunities for the talented individuals. A vigorous drive in the discipline will drastically reduce the rate of unemployment in the country.

- In order to secure recognition of drama as an interdisciplinary programme and as an instructional tool, drama should be recognized and accorded the status of a distinct and curricular subject in the Nigerian pre-varsity educational system.

\section{References}

Allington, A. F. (1961). Drama and Education. Oxford: Basil Blackwell.

Aristotle (1965). Poetics. New York: Charles Scribnews Sons.

Brown, J.R. (ed) (2001). Drama and the Theatre: An Outline for Students. London: Routledge and Kegan Paul.

Castle, E. B. (1996). Principles of Education for Teachers in Africa. Nairobi, Kenya: Oxford University Press.

Coggin, P. A. (1986). Drama and Education: A Historical Survey from Ancient Greece to the Present day. London: Thames and Hadson.

Courtney, R. (1998). The School Play. London: Pitman and Sons, 1998. 
ECA/UNESCO (1993). Report of Conference on the Development of Higher Education in Africa.

Fafunwa, B.A. (1974). History of Education in Nigeria. London: George Allen and Unwin.

Federal Republic of Nigeria (1997). National Policy on Education. Lagos: Federal Ministry of Education.

Harley, G.B. (2006). The Use of Drama. London: Sidgwick and Jackson.

Hodgson, J. \& Banham, M. (eds.) (1975). Drama in Education (The Annual Survey3). London: Pitman \& sons.

Honby, A. S. (2005). Oxford Advance Learner's Dictionary of Current English (7th Edition). London: Oxford University Press.

Peters R.S. (1993). The Philosophy of Education. London: Oxford University Press.

Slade, P. (1974). Child Drama. London: University Press.

Umukoro, M.M. (2002). Drama \& Theatre in Nigerian Schools: A blueprint of Educational Drama \& Theatre. Ibadan: Caltop Publications (Nigeria) Limited.

Warnock, M. (2003). Development through Drama. London: Longmans. 